\title{
THE READER AS SPECTATOR
}

The Direct Speech Opening in Eighteenth and Nineteenth-Century German Fiction

,Was ist das. - Was - ist das ..."

„Je, den Düwel ook, c'est la question, ma très chère demoiselle."1 With this brief and mystifying passage of dialogue Thomas Mann's novel Buddenbrooks begins. Readers accustomed to being provided, at the outset, with information regarding the time and place of the action or the characters may well be slightly bewildered by Thomas Mann's seemingly improvisational opening. Who are the speakers and what are they actually saying? The beginning of Buddenbrooks appears to be designed to stir the reader's interest by discarding the orderly progress of narration. We are plunged right into the middle of a strange conversation in which the utterances of one speaker stand out particularly because of their quaint mixture of Low German and French. Then the author scatters bits of expository material over the next few pages. As if to tease us he adds a second more customary beginning after we have started to catch up with him: "Man saß im 'Landschaftszimmer', im ersten Stockwerk des weitläufigen alten Hauses in der Mengstraße, das die Firma 'Johann Buddenbrook' vor einiger Zeit erworben hatte und das die Familie noch nicht lange bewohnte..."2 By this time, finally, we are able to identify the various members of the three generations of the Buddenbrook family assembled here.

Attempts have been made to link the opening of Buddenbrooks with literary and cultural trends around the turn of the century. According to Wolfdietrich Rasch, writers at that time often present "in akzentuierter Weise das Erzählte als bloßen Ausschnitt aus einem größeren Ganzen . . . von dem es sich in unscharfen, verfließenden Grenzen abhebt."3 $\mathrm{He}$ believes that parallels exist between impressionist paintings and the abrupt beginnings in some of Thomas Mann's works, among them Buddenbrooks. V. Zmegač, on the other hand, tries to establish a connection between this type of fictional opening and naturalist theory which objected to artistic conventions removing art from life. ${ }^{4}$ In his view the open beginning would be in keeping with the naturalist idea that art can only represent more or less arbitrarily selected slices from the inexhaustible fullness of life. Zmegač furthermore suggests that the openings in War and Peace or in some of the novels by the Goncourts might have inspired Thomas Mann to employ direct discourse at the very beginning of Buddenbrooks. However, both Rasch and Zmegač overlook the fact that here Thomas Mann makes sophisticated use of a fictional technique which had become well established before the Goncourts or Tolstoy wrote their novels and which he must have come across repeatedly in the course of his wide reading. The openings of novels have received increased 
attention by critics in recent years ${ }^{5}$ but the direct speech beginning has hardly been investigated. This paper will concern itself with the emergence and the functions of this device in eighteenth and nineteenth-century German fiction.

It is in the second half of the eighteenth century, an age which is in general marked by a great deal of experimentation with the novel that the direct speech opening begins to be employed more widely. ${ }^{6}$ Johann Carl Wezel's pessimistic novel Belphegor oder die wahrscheinlichste Geschichte unter der Sonne (1776) provides us with a relatively early example of this narrative method. Like numerous authors who were to use it later, Wezel starts off in the middle of a significant event. We immediately observe Belphegor in the first of many disillusioning scenes of violence and deception, which undermine his idealizing preconceptions about his fellow human beings: ${ }^{7}$

„Geh zum Fegefeuer mit deinen Predigten, Wahnwitziger!" rief die schöne Akante mit dem jachzornigsten Tone und warf den erstaunten, halb sinnlosen Belphegor nach zween wohlabgezielten Stößen mit dem rechten Fuße zur Thüre hinaus.

Undoubtedly Akante's rabid language which accompanies her vicious attack on her lover heightens the impact of this abrasive opening. It is almost immediately followed by the "wohlgesezte Klage" of the uncomprehending Belphegor, which begins to clarify the circumstances leading to the initial situation. However, since Wezel provides a framework for the reader by outlining the characters and themes of his book in his preface, the surprise effect and the feeling of momentary disorientation typical of the direct speech opening is lessened. Of the numerous late eighteenth-century narratives which likewise start out with a passage of direct discourse we can only mention a few here: Das Intelligenzblatt and Das Wort zur rechten Zeit, both by anonymous authors in the 1777 volume of the magazine Deutsches Museum; H. P. Sturz's Die Reise nach dem Deister (1778), Christian L. Heyne's Antonie (1783), K. Ph. Moritz' Andreas Hartknopf (1786), and Heinse's Hildegard von Hohenthal (1795). ${ }^{8}$

Perhaps the most prominent German novel from this period in which an opening in direct speech occurs is Tieck's Franz Sternbalds Wanderungen (1798). Like Wezel, Tieck rightaway establishes ideas central to his book, in this case the theme of wandering with its associated motifs of leavetaking and reunion: 9

,So sind wir denn endlich aus den Toren der Stadt”, sagte Sebastian, indem er stille stand und sich freier umsah.

"Endlich?" antwortete seufzend Franz Sternbald sein Freund.

"Endlich? Ach nur zu früh, allzu früh."

Die beiden Menschen sahen sich bei diesen Worten lange an, und Sebastian legte seinem Freunde zärtlich die Hand an die Stirne und fühlte, daB sie heiß sei. - „Dich schmerzt der Kopf", sagte er besorgt, und Franz antwortete: „Nein, das ist es nicht, aber da $B$ wir uns nun bald trennen müssen."

„Noch nicht!" rief Sebastian mit einem wehmütigen Erzürnen aus, „,so weit sind wir noch lange nicht, ich will dich wenigstens eine Meile begleiten." 
By postponing such preliminary matter as the time and place of the action, the family and occupational background of the two friends as well as reflections by the narrator, Tieck focuses our interest on the intense farewell between Franz Sternbald and Sebastian. The reader is at once called upon to try to interprete their emotional words and gestures. Already in this scene Franz Sternbald's oversensitive nature begins to reveal itself. But unlike Thomas Mann who exploits the information delay characteristic of all types of in medias res beginnings, Tieck is not interested in mystifying us; he very soon discloses such facts as the names of the two speakers and their relationship. However, following the initial passages of direct speech, Tieck, like the other authors discussed so far, narrates his plot both backwards and forwards in time, a technique necessitated by the abruptness of in medias res beginnings.

It is not by accident that the direct speech opening first becomes popular during the second half of the eighteenth century. To be sure, as a variant of the in medias res beginning it derives, in part, from a convention primarily associated with the epic, whose best-known formulation can be found in Horace's Ars Poetica (v. 148-150). Eighteenth-century poetics repeatedly advise the novelist to adopt this epic technique. Already Pierre Daniel Huet, who in general looks upon the epic as a model for "les romans reguliers," 10 had made this point in his tract Sur l'Origine des Romans (1669). ${ }^{11}$ In his Critische Dichtkunst Gottsched clearly prefers the in medias res opening because he finds it artistically superior. ${ }^{12}$ Not surprisingly, quite a few works from the seventeenth and early eighteenth century, among them Anton Ulrich von Braunschweig's Die durchleuchtige Syrerin Aramena (1678), have this type of beginning.

However, this adaptation of an epic convention to prose fiction cannot explain why the device with which we are concerned here becomes popular only later in the eighteenth century. I would like to suggest that this development, which is paralleled by a general increase of direct speech in fiction, is related to the fact that around the middle of the eighteenth century critics begin to emphasize the use of direct speech as the supreme method of involving and teaching the reader. I will try to show that ultimately the direct speech opening can be regarded as a manifestation of the reorientation of fiction towards the dramatic which takes place in the eighteenth century.

Already the Swiss critics are aware of the shortcomings of straightforward reporting by the narrator. Without specifically referring to the novel, Johann Jacob Breitinger tells authors to let their characters express themselves in order to heighten the reader's illusion:13

Der Poet würde die Gemüthes $=$ Gedancken seiner Personen durch das einfältige Erzehlen nur frostig machen, die starckgezeichneten Züge und die Heftigkeit würden verschwinden; wenn ich hingegen die Person selber vernehme, und so zu sagen, die Leidenschaft von der ersten Hand empfange, so nehme ich dieselbe also bald an mich, ich theile sie mit ihm, die Anreden und andere Figuren hintergehen mich, ich werde 
aus einem Leser ein Zuseher, ich vergesse den Poeten, und ich sehe, ich höre alleine, die Person, die er einführet, und der er etwas zu reden giebt. Darum ist der dramatische Theil der Poesie auch der vornehmste und beweglichste, weil er die vollkommenste Art der Nachahmung ist.

In his state of "süssen Irrthums"14 the reader resembles a spectator who has been overcome by events on the stage - an image repeatedly used by later critics when discussing vividness and liveliness in fiction. ${ }^{15}$ Breitinger, who like many eighteenth-century authors considers the drama the most valuable genre because of its power to involve the audience, ${ }^{16}$ implies that through the proper use of direct speech writers should aspire towards the immediacy of presentation typical of drama. Even though the admixture of direct discourse in the epic had been noted as long ago as in Aristotle's Poetics (ch. 24), its much more extensive and intense use in the drama now comes to be looked upon as the model for lively storytelling. This idea which marks a significant step towards a more flexible view of the interrelationships of literary genres was to be elaborated on by important works on the theory of fiction, Friedrich von Blanckenburg's Versuch über den Roman and Johann Jakob Engel's Über Handlung, Gespräch und Erzehlung, both of which appear in 1774.

Blanckenburg believes that literature in general and the novel in particular should instruct the reader in such a manner that he has to draw his own inferences: "Lohnt es sich nicht der Mühe, die Menschen denken zu lehren? - Es ist gewiß das Edelste, das der Dichter lehren kann." 17 As a result, he is opposed to the predominance of "bloße Erzählung"18 as well as "das bloße Moralisiren des Dichters"19 in fiction and he strongly advocates that the novelist emulate the dramatist. The voices of his figures should be heard frequently so that the reader's imagination is aroused and he can thus form his own judgment. Blanckenburg approvingly quotes a passage from Home's Elements of Criticism (1761) in which the concept of the reader as spectator, which we have already encountered in Breitinger's Critische Dichtkunst, again figures prominently: ${ }^{20}$

Jeder Mensch von einigem Nachdenken muß gemerkt haben, daß ein Vorfall einen weit stärkern Eindrück auf einen Augenzeugen macht, als auf dieselbe Person, wenn sie von einem dritten ihn erst erfährt. Scribenten von Genie, welche wissen, daß das der beste Zugang zum Herzen ist, stellen jedes Ding so vor, als ob es vor unsern Augen vorgienge, und verwandeln uns gleichsam aus Lesern und Zuhörern in Zuschauer. Ein geschickter Scribent verbirgt sich und läßt nur seine Personen sehen; mit einem Wort, alles wird dramatisch, so sehr es nur immer möglich ist.

Adopting one of Home's central aesthetic terms, Blanckenburg considers it the primary task of the novelist to achieve "ideale Gegenwart,"21 that is to say the artist should transpose the reader entirely into the world of the work of art, even if this leads to the mixture of supposedly segregated genres. ${ }^{22}$

While J. J. Engel is not exclusively concerned with the novel, he, too, 
contributes towards the emancipation of the novel from the epic ${ }^{23}$ and its closer affiliation with the drama through his investigation of the potential of direct discourse. His elaborate comparisons of "Gespräch" and "Erzählung" point out the various advantages of using direct speech in narration. What is most important to our discussion is his view that "der Erzehler" always remains oriented towards the past:24

er kann der Imagination, durch Verwechselung der Zeitfälle, in ihrem Bestreben nach Gegenwart und Anschauen zu Hülfe kommen; aber so ganz kann er sie doch nie in die Wirklichkeit hineinsetzen, als der Dialogist, bey welchem alles Gegenwart, alles jetziger Augenblick ist.

And he underlines the possibilities of direct discourse for character portrayal: 25

Die Erzehlung nehmlich kann von dem jedesmaligen Zustande einer handelnden Seele; sie kann auch von dem ganzen genauen Zusammenhange aller in ihr vorgehenden Veränderungen nie eine so specielle, bestimmte, vollständige Idee geben, als das Gespräch.

Like Blanckenburg and other authors cited earlier, he, too, associates immediacy and vividness of presentation with dialogue in drama: "Der Erzehler gehe also... sobald es auf Schilderung der Seele ankömmt, ins Dramatische über..."26

While none of the critics discussed so far deal specifically with the direct speech beginning, their increasingly penetrating investigation of the potential of direct discourse and its link with the drama undoubtedly forms part of the background for the emergence of this technique in the second half of the eighteenth century. Such openings, which at about the same time also start to make their appearance at chapter beginnings within works of fiction, reduce the role of the narrator and establish immediate contact between the characters and the reader so that already at the very outset he is put into the position of a spectator, as it were. This fictional method seems capable of realizing Blanckenburg's idea of how the writer should introduce his figures: ${ }^{27}$

Man würde mich sehr unrecht verstehen, wenn man glaubte, daß ich also verlange, der Dichter solle uns so gleich alle seine Personen, auf den ersten Anblick, charakterisiren, und eine Beschreibung ihrer ganzen Denkungsart voran schicken ... Der Dichter soll dem Leser Gelegenheit geben, die erscheinenden Menschen selbst kennen zu lernen ... Dann nur wird er Lehrer seines Lesers!

In order to have a more comprehensive understanding of the historical context within which the direct speech opening becomes popular we have to keep in mind related tendencies towards the dramatic in the eighteenth century. First of all, decades before Tieck employs direct speech so amply in his Novellen, the use of this method seems to increase considerably. In such works as Heinse's Hildegard von Hohenthal (1795) 
direct speech constitutes a surprisingly large portion of the text. Furthermore, several so-called dialogue novels appear towards the end of the eighteenth century, in which this trend is carried to an extreme. Friedrich Traugott Hase's novel Gustav Aldermann (1779), which bears the characteristic subtitle Ein dramatischer Roman, starts in the middle of a conversation and, except for occasional brief "stage directions," excludes the narrator entirely. ${ }^{28}$ Also the popular form of the epistolary novel, in which for the most part the figures speak for themselves, is at that time frequently associated with the drama." 29 Even the school of "pragmatic" historians, who likewise attempt to transform their readers into involved spectators, reinforce the orientation of late eighteenth-century fiction towards the drama. ${ }^{30}$ Finally, the popularity of the dialogue as a literary genre might also have encouraged a greater use of direct discourse in fiction.

The technique of starting off in the middle of a conversation or with a soliloquy reaches its culminating point in the first half of the nineteenth century, with many important authors using it in some of their works. ${ }^{31}$ If we are to believe Tieck and Hoffmann, readers had become so accustomed to in medias res beginnings that authors ran the risk of boring them with a less immediate opening. ${ }^{32}$ In Der Sandmann Hoffmann playfully resists such pressures by discarding a dialogue opening and two more traditional versions of beginning his story and pretending not to begin at all.

The fact that in his later works Tieck uses direct speech as well as the direct speech opening more frequently than in his youth is perhaps symptomatic of trends in early nineteenth-century fiction. ${ }^{33}$ Several of his Novellen, among them Die Gemälde (1821), Die Verlobung (1822), the first part of Dichterleben (1825), Das Zauberschloß (1929), and Wunderlichkeiten (1836) start with direct speech but he handles this technique most convincingly in Die Elfen (1811) and in Der Aufruhr in den Cevennen (1826). Tieck's fairytale Die Elfen seems to start out within the bounds of familiar reality, with what seems to be a matter-of-fact conversation between the parents and two of their children. The brief remarks of these figures, although based on their limited perspective, are nevertheless designed to convey a few warning signals to the reader; for example, they arouse in us vague premonitions concerning Marie's absence and the possible dangers of the woods. Thus, almost imperceptibly, Tieck begins to prepare us for the transition to the realm of the miraculous and the threat which it constitutes to the apparently ordered and prosperous existence of the family. On the other hand, the historical novel Aufruhr in den Cevennen starts on a much more ominous note, partly because most of the speakers are aware of the dangers surrounding them. Already the opening conversation is, directly or obliquely, dominated by the strife between the Huguenots and the Catholics. The menacing approach of the thunderstorm from the mountains, which the dialogue touches on, is 
meant to allude to the dangers posed by the Huguenots who, as we soon learn, operate from that very region. Even the precocious remarks of the little daughter contribute towards the oppressive atmosphere of this beginning since to the anguish of her father she unthinkingly echoes the propaganda of the Catholic party who identify their opponents with Satan. Thus Tieck shows us from the very beginning of his novel how the fate of his figures is inextricably bound up with historical developments.

Tieck also uses the direct speech opening in order to initiate us casually into the discussions of the frame in Phantasus. Such beginnings occur in quite a few frames written later in the nineteenth century, most notably Hoffmann's Serapionsbrüder. ${ }^{34}$ They seem to be particularly suited to this type of narration because they immediately focus the reader's attention on the gregarious character of the frame technique. Conversations among the narrators and listeners had long been a part of this tradition but a presentation of their exchanges by means of long passages of direct discourse such as dominate the frame in Phantasus or Serapionsbrüder from the very beginning is, at least in part, linked to the continuation of the tendency towards more immediate and dramatic modes of narration pioneered by the later eighteenth century.

Several cultural circumstances seem to favor this continuing trend. Undoubtedly it is furthered by the synthesizing attitudes of the romantics towards literary genres and, later on, by what F. Sengle has called the "stilistische Sorglosigkeit" of the Biedermeier era. Furthermore, the extensive use of direct discourse, both at the very beginning and throughout fictional works must have been especially appealing in an age in which the Brockhaus Conversations-Lexikon becomes something of a bestseller. ${ }^{35}$ In fact, the interest which Tieck's later Novellen arouse in their own time is partly due to the fact that he gives his readers ample opportunities to observe the figures in the act of discoursing upon issues of current interest. Typically, Solger is thrilled by the discussions in the Phantasus frame because they remind him of the considerable conversational talent of his friend. ${ }^{36}$ Naturally the continuing popularity of the dialogue form, which in some works such as Caroline von Fouqué's Fragmente aus dem Leben der heutigen Welt (1820) almost merges into the Novelle tradition, also contributes towards the wide use of direct discourse.

The increase of direct speech in early nineteenth-century fiction attracts frequent comments from contemporary critics who invariably relate this phenomenon to the drama. Thus in 1827 an anonymous reviewer makes the following observations on Tieck's later productions: ${ }^{37}$

Jene Novellen haben das einfache Gebiet der Exzählung verlassen und sich dem Drama genähert, oder um es anders zu sagen, im Gespräch entwickeln sich jetzt die Charaktere von selbst, deren Entwicklung uns sonst nur angedeutet oder beschrieben, erzählt wurde. 
He goes on to say, though, that unfortunately other writers have adopted this method for their almanac stories and vulgarized it. Writing two decades later, Rudolf Gottschall strongly advises authors to create an atmosphere of immediacy, especially at the beginning of a novel: 38

Lange Beschreibungen von Gegenständen, Verhältnissen, Charakteren sind besonders an Anfang des Romans von ertödtender Wirkung ... Die allmählich wachsende Klarheit soll mehr durch die Handlung, durch Gespräch und Brief, durch eine selbstständige Entwicklung der Helden von innen heraus hervorgehoben werden als durch die Beschreibung des Dichters. Der Anfang des Romans ist gewissermaßen am glücklichsten entworfen, wo wir gleich in irgendeine fesseinde Situation, einen Knotenpunkt der Handlung versetzt werden, dessen Fäden zugleich nach rückwärts und vorwärts weisen.

In the context of his studies on the novel, Otto Ludwig expresses his admiration for Dickens' use of direct speech: ${ }^{39}$

Seine Darstellung ist überaus dramatisch, ja theatralisch, jedes Kapitel eine Szene eines Dramas; er hat sogar Expositionen, die im Dialog gegeben werden, wie im konzentrierten Drama ... Seine Romane sind erzählte Dramen mit Zwischenmusik, d.i. erzählter.

Ludwig sees direct speech as an important method of creating "den Anschein der Objektivität der Darstellung ... denn je weniger der Autor in Person sich darein mengt, die Illusion momentan aufhebend, desto besser!" 40 His emphasis on the proximity of the drama and the novel reminds one of eighteenth-century discussions of this subject; 41 for example, his differentiation of ordinary and scenic narration resembles Engel's distinction between "Erzehlung" and "Gespräch". He, too, prefers more immediate forms of presentation because they intensify the reader's illusion and, like Blanckenburg and Home, he uses the central image of the reader as spectator in order to illustrate this point: ${ }^{42}$

Der Erzähler bedient sich aller der mimischen Mittel, durch welche der Dramatiker seinen Vorgang vor das äußere Auge und Ohr des Zuschauers stellt, um den Leser zu einer Art Zuschauer und Zuhörer zu machen, der seine Gestalten sieht und thre Reden hört - aber mittelst des inneren Sinnes.

However, in the course of the nineteenth century scepticism towards the dramatizing tendencies in fiction begins to manifest itself. W. Menzel, for example, points out that direct speech can all too easily be put to mercenary uses: 43

Der epische Charakter des Romans ist immer mehr in einen dramatischen übergegangen. Wo nun der Dialog natürlich und am rechten Ort ist, wollen wir ihn nicht tadeln. Allein es scheint, er werde zum Überfluß bei den unbedeutendsten Anlässen angebracht und überall zu weit ausgedehnt. Oft scheint es, die Dichter gefallen sich darin nur deßwegen, um schneller die Bogenzahl zu füllen, da ein leichter Dialog mit häufig abgebrochenen Zeilen mehr Papier consumiert, als eine ununterbrochene Erzählung.

A more fundamental objection is raised by the influential F. Spielhagen 
later in the century who believes in "die natürlichen Grenzen der Gattungen." 44 As opposed to $O$. Ludwig, he reorients the novel towards the epic and argues against novelists who adopt techniques from the drama "um durch den unepisch beschleunigten Gang der dargestellten Handlung, durch die Darstellung selbst in ihrer dramatisch-szenischen Lebendigkeit, das Vorherrschen des pointierten Dialogs u.s.w. eine erhöhte Wirkung auf das Publikum zu erzielen." 45 Such reactions against the influence of the drama on the novel may, in part at least, account for the more moderate use of direct speech $^{46}$ as well as the direct speech opening in the latter part of the nineteenth century. ${ }^{47}$

University of Michigan

HERMANN F. WEISS Ann Arbor

Notes

1. Thomas Mann, Buddenbrooks (Berlin, 1963), p. 5.

2. Ibid., p. 7 Oskar Walzel has called the opening of Buddenbrooks a riddle (,,Objektive Erzählung", GRM 7 (1915), 168). Once the reader has finished this novel he will recognize how artfully Mann coordinates the beginning with the ending. Toni, surrounded by her family at the outset, stands practically alone in the end; the final scene is one of grief while the initial one is lighthearted; Toni now doubts articles of the Christian faith which she had unthinkingly memorized at the beginning.

3. „Eine Beobachtung zur Form der Erzählung um 1900. Das Problem des Anfangs erzählender Dichtung", in Stil- und Formprobleme der Literatur, ed. P. Böckmann (Heidelberg, 1959), p. 452.

4. "Zur Form und Funktion des Erzählereinsatzes bei Thomas Mann", Sinn und Form, Sonderheft Thomas Mann 1965, pp. 255-267.

5. See esp. Romananfänge. Versuch zu einer Poetik des Romans, ed. Norbert Miller (Berlin, 1965); Norbert Miller, Der empfindsame Erzähler. Untersuchungen an Romananfängen des 18. Jahrhunderts (München, 1968); less valuable: Fritz Leib, Erzählungseingänge in der deutschen Literatur, Diss. Gießen 1912 (Mainz, 1913).

6. It is occasionally used earlier, for example in H. A. von Ziegler und Klipphausen's Asiatische Banise (1689) where the opening monologue seems, however, relatively detached from the subsequent text.

7. Belphegor, ed. Hubert Gersch (Frankfurt, 1965), p. 11.

8. Even Goethe's Hermann und Dorothea seems to partake of this trend. See Joyce M. Tompkins, The Popular Novel in England 1770-1800 (London, 1932), p. 339, on the popularity of the direct speech opening in the English novel around 1790.

9. L. Tieck, Werke in vier Bänden, ed. M. Thalmann, vol. I (Darmstadt, 1968), p. 701.

10. Lettre-traité de Pierre-Daniel Huet sur l'origine des romans, ed. Fabienne Gégou (Paris, 1971), p. 102.

11. Ibid., p. 76.

12. Versuch einer Critischen Dichtkunst, 4th ed. (Leipzig, 1751), p. 527f.

13. Critische Dichtkunst, ed. Wolfgang Bender (1740; facsimile rpt. Stuttgart, 1966), vol. I, p. 470.

14. Ibid., p. 65.

15. What Johann Jacob Bodmer admires particularly in Anton Ulrich's Aramena is the „Kunstgriff der Aufführung oder Handlung, indem der Dichter das Wenigste in seiner eigenen Person redet, sondern Leute für sich selbst reden läßt, wodurch ihre Erzehlungen selber zu Handlungen werden ..." (Critische Betrachtungen über die poetischen Gemählde der Dichter (Zürich, 1741), p. 551). See also pp. 480, 492. In his Praktische Abhandlung von dem guten Geschmacke in Briefen (1751) Gellert advises authors to tell their stories in such a manner ,daß man die Sache nicht allein versteht, sondern daß man glaubt, sie selbst zu sehen, und ein Zeuge davon zu seyn ..." This effect can be best achieved, he believes, ,wenn man die Personen zuweilen selbst reden läßt, und uns dadurch mit ihrem Charakter bekannt macht." (Sämtl. Schriften, 
1. Theil (Bern, 1767), p. 87).

16. See, for ex., Henry Home, Elements of Criticism, vol. I (Edinburgh, 1788), p. 96.

17. Versuch über den Roman, ed. Eberhard Lämmert (1774; facsimile rpt. Stuttgart, 1965), p. 301-302.

18. Ibid., p. 494.

19. Ibid., p. $\mathbf{5 1 0 .}$

20. Ibid., pp. 499-500. J. N. Meinhard published a translation in 1765-1766. See this passage in Home, op. cit., vol. II, p. 351. Apparently the concept of the reader as spectator is an ancient topos: "Plutarch de gloria Atheniensium, observes, that Tucydides makes his readers a spectator, and inspires him with the same passions as if he were an eyewitness..." remarks Home immediately following the passage quoted by Blanckenburg.

21. Versuch über den Roman, p. 493. See Home, vol. I, p. $90 \mathrm{ff}$.

22. Blanckenburg considers the idea „daß man die verschiedenen Gattungen der Dichtkunst nicht mit einander vermischen müsse" as a mere „Wahn" (p. 515); Home expresses similar views (vol. II, pp. 371ff).

23. Cf. Klaus R. Scherpe, Gattungspoetik im 18. Jahrhundert. Historische Entwicklung von Gottsched bis Herder (Stuttgart, 1968), pp. 159ff.

24. Über Handlung, Gespräch und Erzählung, ed. E. Th. Voss (1774; facsimile rpt. Stuttgart, 1964), pp. 56-57. Home also touches upon the dramatic effect of the historical present (vol. I, pp. 98ff).

25. Ibid., p. 57.

26. Ibid., p. 63.

27. Versuch über den Roman, p. 438.

28. For further information on this type of narrative, see Hans G. Winter, „Probleme des Dialogs und des Dialogromans in der deutschen Literatur des 81. Jahrhunderts", Wirkendes Wort 20 (1970), 33-51; also Klaus-Peter Hinze", Goethes Dialogerzählung Die guten Weiber. Ein mißlungenes Experiment", Neophilologus LVI (1972), 67-71.

29. Cf. Wilhelm Vosskamp, „Dialogische Vergegenwärtigung beim Schreiben und Lesen. Zur Poetik des Briefromans im 18. Jahrhunderts", DVLG 45 (1971), 80-116.

30. Cf. Georg Jäger, Empfindsamkeit und Roman. Wortgeschichte, Theorie und Kritik im 18. und frühen 19. Jahrhundert (Stuttgart, 1969), pp. 114ff.

31. E. T. A. Hoffmann (Der Magnetiseur; Der Sandmann; Der Zusammenhang der Dinge; Der Feind), A. v. Arnim (Die drei liebreichen Schwestern und der glückliche Färber; Seltsames Begegnen und Wiedersehen; Metamorphosen der Gesellschaft), W. Hauff (Die Sängerin; Der letzte Ritter von Marienburg), Auerbach (Der Tollpatsch aus Amerika; Des Lorles Reinhard; Joseph im Schnee), Laube (Gräfin Chateaubriant; Der belgische Graf) etc.

32. Tieck makes this point at the beginning of Peter Lebrecht, Hoffmann at the beginning of Meister Floh.

33. Marianne Thalmann (Ludwig Tieck, „Der Heilige von Dresden”' (Berlin, 1960), p. 132) notices Tieck's extensive use of direct discourse without fully accounting for the fact that quite a few of bis contemporaries also employ this method, or example Zschokke in Die isländischen Briefe (1803) or Der Eros oder über die Liebe (1821).

34. Further examples: Leopold Schefer's Unglückliche Liebe and Der Kuß des Engels; Heyse uses the direct speech opening almost exclusively for the purpose of introducing frame situations, for example in Die Wittwe von Pisa, Das schöne Käthchen, Die Tochter der Excellenz,'s Lisabethele etc.

35. According to F. A. Brockhaus' postcript to the third imprint of the fifth ed. of his Allgemeine deutsche Real-Encyclopädie für die gebildeten Stände, he sold the first imprint of the 5th ed. (12000) within one year of its appearance (1818-1820); the 2nd imprint (10000) was sold in 1820 .

36. Letter to Tieck dated Aug. 4, 1816 (Percy Matenko, Tieck and Solger. The Complete Correspondence (New York, 1933), p. 270).

37. Quoted from Theorie und Kritik der deutschen Novelle von Wieland bis Musil, ed. K. K. Polheim (Tübingen, 1970), p. 58.

38. Poetik (Breslau, 1858), p. 383.

39. Gesammelte Schriften, vol. VI, ed. A. Stern (Leipzig, 1891), p. 66.

40. Ibid., p. $125 \mathrm{f}$.

41. „Der Roman liegt überhaupt dem Drama näher als dem Epos.” (Ibid., p. 67.).

42. Ibid., p. 203. 
43. „Die Romane”, Deutsche Viertel-Jahresschrift 1 (1838), p. 132.

44. Beiträge zur Theorie und Technik des Romans (Leipzig, 1883), p. 294.

45. Ibid., p. 293.

46. Compared to Tieck's Novellen or to such works as W. Alexis' Der Werwolf (1848) and Ruhe ist die erste Bürgerpflicht (1852), Fontane's use of direct speech seems more moderate.

47. For example, of all the stories published in the Deutsche Rundschau between 1874 and 1879 only two have this type of beginning whereas one can usually find at least one example per almanac 50 years earlier. However, this device continues to be used in meaningful ways, for example in Fontane's Grete Minde. It is primarily through the dialogue between Grete and Valtin that we experience their innocent encounter which is already overshadowed by their awareness of the rigid and unkind attitudes of Grete's fostermother. 